\title{
Student Voice: Learning with Gadget vs Learning with Real Teacher
}

\author{
Dewi Nopita, Benni Satria, Hanifah \\ dewinopita@umrah.ac.id, bennisatria@umrah.ac.id, hanifah@umrah.ac.id \\ Universitas Maritim Raja Ali Haji (UMRAH), Universitas Maritim Raja Ali Haji(UMRAH), \\ Universitas Maritim Raja Ali Haji (UMRAH)
}

\begin{abstract}
This research explored students' perceptions and experiences of online and offline lecturing in the English Language Education Study Program (ELESP) at Universitas Maritim Raja Ali Haji (UMRAH). The sample population was drawn from fourth-semester ELESP students in the 2021 academic year. Forty students from the essay writing class enrolled in the online and offline program were asked to write a paper on experiences and perceptions of online and offline lecturing. Subsequently, data was collected using open-ended questionnaires and online interviews. The results showed that students preferred offline learning to online learning because it provided incredible benefits and fewer weaknesses.
\end{abstract}

Keywords: Online learning, Perception, Offline Learning

\section{Introduction}

Presently, there are three modes of learning, including offline, blended, and online. Offline learning is conducted in a classroom environment using face-to-face interaction, while blended learning is a mixture of online and face-to-face methods and online learning relies on the internet. The method allows students to learn autonomously, although there is an interpersonal relationship with teachers.

The Covid-19 pandemic resulted in lockdowns across the globe, including the closure of schools. Before the pandemic, teachers could use any of the three modes of teaching. However, the pandemic compelled higher education institutions to use online learning to overcome academic disturbance. The transformation of the learning mode created various challenges ranging from the infrastructure, students to educators.

Online learning is a relatively new way of studying for developing countries such as Indonesia. Previously, the educators relied mostly on offline learning and blended learning. Consequently, they hadn't mastered how to prepare and design learning activities. Some studies [5], [6], and [7] have been conducted on how online learning effected developing countries during a pandemic. However, there is little evidence on how students perceive online learning. Through a narrative, this research aims to explore students' perceptions and experiences towards online and offline learning.

[1] stated that the teacher plays a critical role in learning as a facilitator, mediator and curriculum designer. Teachers help to create a conducive learning atmosphere and provide learning activities to enable students to remain active. Learners also take an active role by being fully engaged in the learning process.

According to [9], online learning involves using electronic networks from any place and is conducted in real-time. This type of learning has various advantages, including flexibility, 
allowing students to allocate time and learn at their own pace. Moreover, it enables students to have online discussions and collaboration with peers and tutors. The feedback from teachers and peers deepens the understanding of the course content.

Following a lockdown, the learning process in Universitas Maritim Raja Ali Haji was shifted to online platforms to keep the academic activities moving. Previously, the lecturers and students had been using offline learning allowing the instructors to manage, observe, and evaluate the learning process directly. The change of the learning mode forced teachers to select applications to manage the e-learning, such as WhatsApp, video conference, google classroom, and more. The transition from face-to-face to virtual classes was also adopted by the English Language Education Study Program (ELESP) for all courses, especially essay writing. The lecturers handling the courses had to transit from conventional to teaching online.

The objective of this research was to investigate the students' perceptions and experiences on online learning and to have a teacher physically in essay writing classes. The results revealed that the performance of students significantly reduced when they used online learning. Many students who attended online classes were unsuccessful in achieving the learning purposes in the English subject compared to offline studying before the pandemic. The results suggested that there is a need to improve the quality of learning and teaching.

\section{Research Method}

The research used a narrative inquiry to uncover the students' perceptions and experiences towards the learning activities applied in ELESP. According to [2], narrative research involves an in-depth description of the ideas and experiences of the participant. The participants were 40 students studying essay writing, who had been studying offline for one year before the Covid19 pandemic, and online learning after lockdown. The students were asked to write a report about their perceptions and preferences regarding online and offline learning. Online interviews were conducted to confirm their stories, and the data derived revealed the need to improve the quality of learning and teaching activities.

\section{Results}

The main instrument of this research was an open-ended questionnaire. The students were asked to write two texts: their experiences in teaching before the pandemic (offline learning) and their experiences after the pandemic (online learning). Online interviews were also conducted to confirm the participants' perspectives and experiences. The research concluded that $90 \%$ of the participants preferred offline learning to online learning, while the rest felt that offline learning was as effective as online learning. According to the results, the factors that affect students' preference for online learning include educators, media, and learning activities.

First, students reported that lectures failed to adapt to online teaching due to a lack of technical skills, resulting in ineffective monitoring. Technology integration was also a big challenge since most lecturers could not operate e-learning tools, which resulted in technical issues. Subsequently, online learning had technical glitches due to poor internet connection, hence distracting the learning environment. However, in offline learning, teachers address issues quickly due to the direct interaction with students. 
Second, students were required to buy expensive devices for online learning such as internet connections, mobile phones, computers, and more. With the Covid-19 pandemic, people especially students' parents, experienced jobs and income losses, hence it is challenging for students to afford online tools.

Furthermore, students found online learning boring and unengaging since lecturers used similar online teaching tools such as WhatsApp, Video conference, and Google Classroom. Failure to change the teaching and learning style resulted in a lack of motivation. Conversely, offline learning allows lecturers to use different teaching strategies. The classroom environment also promotes collaborative learning, interaction, and motivation.

Lastly, students reported that even though online learning offered 'independent studies' where learners moved at their own pace to achieve their goals, they neither shared ideas nor built knowledge together. Furthermore, students reported sitting for too long, which they felt was not healthy, especially spending too much time in front of screens.

\section{Discussion}

The findings indicated that offline learning is certainly a more effective option for students rather than online. The narrative approach found sufficient evidence to indicate that offline learning is practical and straightforward, and it creates interactive learning where students become more engaged. According to [8], students preferred offline learning because they failed to achieve their academic goals while using online learning. Also, [3] stated that students struggled with online learning due to limited access to technology and resources.

Although [4] claimed that English language learners preferred online learning because of flexibility, the findings revealed that lecturers lacked digital literacy, and most students lacked gadgets and online connectivity. Finally, the results showed that offline learning provided students unlimited interaction with a clear voice and precise meaning. In contrast, gadgets had technical issues such as unclear sound since the signal or system in the audio application could not work properly. Therefore, future research should consider the quality of classroom interactions to achieve the learning goals.

\section{Conclusion}

The results revealed that students had negative perceptions about online education. This was based on the role of the educator, the selected media, and the learning activities. They argued that online educators could not manage and engage students compared to how teachers engaged students using offline learning mode. Furthermore, students experienced technical issues and a lack of understanding while using online learning media. Finally, students reported inadequate online learning activities, which resulted in a 'learning gap.'

Exploring teachers' perceptions and experiences toward online learning and offline learning should be an area of further research. Moreover, additional instruments for data collection will give a more comprehensive understanding of this issue. Future research can address the effectiveness of each digital platform upon specific learning skills, such as speaking and writing skills, using a qualitative or quantitative design. 


\section{References}

[1] Baras, J. S. (2000). Educational connoisseurship and critics. Journal of General Education, $4(2), 213-245$

[2] Connelly, F. M., \& Clandinin, D. J. (1990). Stories of experience and narrative inquiry. Educational Researcher, 19(5), 2-14.

[3] Gherhes, , V.; Stoian, C.E.; F arcas, iu, M.A.; Stanici, M. E-Learning vs. Face-To-Face Learning: Analyzing Students' Preferences and Behaviors. Sustainability 2021, 13, 4381. https:// doi.org/10.3390/su13084381

[4] Rakhmanina. Lisa et.al (2020). Students' perception on online English learning during Covid-19 Pandemic Era. Jurnal Pendidikan Bahasa Indonesia, Daerah, dan Asing (SILAMPARI BISA), 3(2), 428-439

[5] Purushotham, S. L., \& Swathi, Ch. (2020). Online learning and its effects on English language skills among higher education students amid the COVID-19. Language in India, 20(9), 127-144.

[6] Rahim, A., Ali, S., Ali, S., \& Fayyaz, H. (2020) Online education during COVID-19 pandemic: An experience of RIPHAH International University Faculty of Health and Medical Science. Pakistan Armed Forces Medical Journal, 2, 506-513.

[7] Schlesselman, L. S. (2020). Perspective from a teaching and learning center during emergency remote teaching. American Journal of Pharmaceutical Education, 84(8).

[8] Syauqi, K., Munadi, S., \& Triyono, M.B. (2020). Students' perceptions toward vocational education on online learning during the COVID-19 pandemic. International Journal of Evaluation and Research in Education (IJERE), 9(4), 881-886

[9] Villegas-Reimers, E. (2008). Teacher professional development: An international review of literature. Paris: UNESCO. 